\title{
Forty Years After the Islamic Revolution of Iran: An Indonesian Perspective
}

\author{
Dicky Sofjan \\ Indonesian Consortium for Religious Studies (ICRS) \\ Universitas Gadjah Mada, Yogyakarta \\ dickysofjan@ugm.ac.id
}

\begin{abstract}
Following 40 years of Khomeini's Islamic Revolution in Iran, how does Indonesia view Iran then and now? Is the exportation of the Revolution now relevant amid the contemporary political constellation in the Middle East and the world? Does Shia Islam remain to pose a sociopolitical problem today in the largest Muslim nation? In view of the current political standoff with the United States of America, will the system, based on Velayat-e Fagheh (Guardianship of the Jurist), remain strong against all odds? This article explores these questions based on personal reflections, experiential learning and continuous engagement in and with Iran.
\end{abstract}

[Setelah 40 tahun Revolusi Islam pimpinan Khomeini berhasil memukau dunia, menarik untuk melihat pandangan Indonesia terhadap Iran, yang dulu dan sekarang. Apakah semangat revolusi masih relevan terkait dengan konstelasi politik Timur Tengah dan dunia kontemporer? Apakah persoalan Syiah masih dipandang sebagai pemicu berbagai problema sosio-politik di Indonesia? Melihat permusuhan Amerika terhadap Iran, apakah sistem Velayat$e$ Fagheb (Kepemimpinan oleh Faqih) masih relevan menghadapi berbagai tantangan yang dihadapi Iran saat ini? Artikel ini berupaya mengeksplorasi pertanyaan-pertanyaan di atas berdasar refleksi dan pengalaman personal serta pengamatan terhadap situasi perkembangan di Republik Islam Iran.]

Keywords: Islamic revolution, Iran, Indonesia, Islam, Shia, Velayat-e Fagheh. 


\section{Introduction}

The year 2019 marks the $40^{\text {th }}$ anniversary of the Islamic Revolution of Iran. When the 1978/1979 revolution exploded, the world for the most part was dumbstruck. The attitude of the unsuspecting West was subsequently followed by the usual condescension and sarcasm. Many predicted that the Revolution, led by Ayatullah Rohullah Khomeini with his medieval exterior look and seemingly archaic political system, could not possibly stand the test of time. However, the mullabs have evidently proved the world wrong, over and over again.

On July 3, 2017, US President Donald Trump's recently appointed National Security Adviser John Bolton in a "Free Iran Gathering" in Paris was convinced of Iran's imminent collapse and the need for "regime change". "The outcome of the president's [Trump's] policy review should be to determine that the Ayatullah Khomeini's 1979 revolution will not last until its $40^{\text {th }}$ birthday," Bolton said. ${ }^{1}$ He even hinted at celebrating Christmas in Tehran. Wrong again!

Such has been the default attitude of many hawkish US administration high-ranking officials for over four decades. Successive US presidents, from both the Republican and Democratic Parties, from Jimmy Carter to Trump have constantly proven to misjudge Iran's resolve and determination. George W. Bush's labeling of Iran as part of the "axis of evil" was also unhelpful, despite Iran's incessant 'war' against AlQaidah, Daish (Al-Dawlah al-Islamiyah fii al-Iraq wa al-Sham), An-Nusrah and the likes of the Sunni jihadi terror links. ${ }^{2}$

Only president Barack Obama seemed to have given the Iranian government the benefit of the doubt with the nuclear deal—officially called the Joint Comprehensive Plan of Action)—, which was signed in 2015 and then subsequently annulled by Trump. With the current political standoff with the US and the talk of war, it is imperative that the US administration does not commit to the same folly, as was the case in Iraq,

\footnotetext{
${ }^{1}$ See: https://www.ncr-iran.org/en/freeiran2017/23114-john-bolton-iran-regime-mustnot-reach-40th-birthday (accessed on August 7, 2018).

${ }^{2}$ Bush had categorized Iran as an axis of evil together with Kim Jong Il's North Korea and Saddam Hussein's Iraq.
} 
Libya and Syria. A recent statement dated May 24, 2019 by the American College of National Security Leaders, comprising retired admirals, generals, ambassadors and other statesmen warned of the impending mistake if Trump chooses to wage war on Iran. ${ }^{3}$ The statement, which is directed to President Trump, states:

The mutual animosity between the United States and Iran, the accelerated deployment of an aircraft carrier strike group and B-52 bombers to the region, and reports of Iranian preparations for attacks on U.S. military and diplomatic facilities are highly concerning and make for a potentially deadly confrontation. A war with Iran, either by choice or miscalculation, would produce dramatic repercussions in an already destabilized Middle East and drag the United States into another armed conflict at immense financial, human, and geopolitical cost. ${ }^{4}$

The statement further calls on Trump as follows:

As President and Commander-in-Chief, you have considerable power at your disposal to immediately reduce the dangerous levels of regional tension. Crisis de-escalation measures should be established with the Iranian leadership at the senior levels of government as a prelude to exploratory diplomacy on matters of mutual concern. The protection of U.S. national interests in the Middle East and the safety of our friends and allies require thoughtful statesmanship and aggressive diplomacy rather than unnecessary armed conflict. ${ }^{5}$

From the statement, it is clear that American military leaders are fed up with the seemingly relentless and costly war in the Middle East. Any unnecessary wars in the Middle East could quite possibly create further polarization in the American society and alienate the Trump presidency more than it already has now.

3 https://warontherocks.com/2019/05/an-open-letter-to-president-donald-trump-onu-s-tensions-with-iran/ (accessed on May 25, 2019).

${ }^{4}$ Ibid.

${ }^{5}$ Ibid. 


\section{Islamic Revolution and Southeast Asia}

For the vast majority of Iranians, the Revolution represents the triumph of Islam over absolute monarchy led by Shahanshah (King of Kings) Mohamed Reza Pahlevi, who was adamantly backed by the US and its powerful Western allies. Not long after the return from exile of Imam Khomeini to his homeland in February 1979, Iran observers quickly realized that the mullabs were here to stay, and that they were not pushovers.

In fact, the hardline Students Following the Lines of Imam Khomeini gate crashed the US Embassy in Tehran, took it over, and held it hostage for 444 days along with American diplomats and staff members. Since then, diplomatic ties between the two governments have never recovered, until today.

During the tumultuous period of the late 1970s and early 1980s, Indonesia and other Southeast Asian nations were busying themselves with economic development and "structural adjustment" programs imposed upon them to comply with Western financial standards and monetary systems. This was to ensure and secure foreign direct investments in the region. As a result, many Southeast Asian countries was engulfed in what Kunio Yoshihara called "Ersatz Capitalism", ${ }^{6}$ which was brought and bred by the region's authoritarian governments and strongmen of the likes of Suharto in Indonesia, Mahathir Mohamed in Malaysia, Lee Kuan Yew in Singapore and Ferdinand Marcos in the Philippines. ${ }^{7}$

Given such context, these governments obviously did not want the exportation of Khomeini's Revolution to hold sway among the large swath of Muslim populations in their respective countries. If so, such a political scenario would have made Western foreign investors nervous, if not

\footnotetext{
${ }^{6}$ Kunio Yoshihara, The Rise of Ersatz Capitalism in Southeast Asia, Oxford University Press, Singapore, 1988.

${ }^{7}$ While, these post-colonial states were unambiguously under the sway and influence of Western Capitalism, Indo-China states such as Vietnam, Cambodia and Lao PDR were very much under the USSR (now, Russia) and Chinese spheres of influence.
} 
anxious. What is more, the inherent revolutionary spirit of Shia Islam would not at all have been compatible with the economic development and modernization project that were taking place rapidly in these countries.

In Indonesia, Suharto's New Order regime tried to curb the rising expectations in the Islamic Revolution by getting the Majelis Ulama Indonesia (MUI/Indonesian Council of Ulama) to issue a 1984 recommendation against the Shia teachings and doctrines, which they saw as "fundamentally different" from the Sunni strand of Islam as espoused by most Indonesian Muslims. The MUI recommendation suggested that Indonesian Muslims be "vigilant" toward the negative effects of Khomeini's Shia revolution. I have argued elsewhere that such "minoritization" and "criminalization" of Shia Islam stemmed mostly from the New Order's political expediency and religious ignorance, rather than any real theological threat on the Muslim populace, given the predominantly and massively influential local socio-religious groups such as the Nahdlatul Ulama and the Muhammadiyah. ${ }^{8}$

About the same time and for almost the same reason, Malaysia was quick to ban Khomeini's "exportation" of the Islamic Revolution. Mahathir even made sure that the Jabatan Kemajuan Islam se-Malaysia (Jakim), the federal religious authority, banned Shia, and censored its revolutionary books, magazines and pamphlets. For the Malaysian government, Shia Islam posed a threat to the politico-religious establishment where race, religion and politics are intricately intertwined. It was also seen as a political liability with electoral consequences, especially among the more conservative Malay-Muslim constituent, which was essentially the electoral base for the previously powerful National Front and the now fragmented United Malay National Organization (UMNO). ${ }^{9}$

\footnotetext{
${ }^{8}$ See Dicky Sofjan, "Minoritization and Criminalization of Shia Islam in Indonesia". In Journal of South Asian and Middle Eastern Studies, Villanova University, Vol.39 (2), 2016.

9 The more progressive among the Malay-Muslim constituents have now shifted their political allegiance to the Alternative Front or "Coalition of the Hopeful", which won the recent 2018 election, which propelled 93-year-old Mahathir back in power as
} 
In spite of these government restrictions and banning, some Muslim scholars and students from Southeast Asia made the effort to venture to the holy city of Qum in Iran to study. ${ }^{10}$ Since the Revolution, the status of Qum as one of the primary centers of learning for Shias ascended to new heights. At the time, hundreds of scholars and students from around the world came to study under the tutelage of senior Ayatullabs, and subsequently became propagators of Shia Islam back in their respective homelands, albeit only a small number of them actually carried the revolutionary zeal that Khomeini and his followers had initially intended.

\section{Iran After Khomeini}

My first visit to Iran was in 1992 as a visiting student in the International Center for Persian Studies, an institutional affiliate of the famed Danesgha-e Tehran (Tehran University), one of the Revolutionary centers of gravity that brought down the Shah. At the time, my late father was a career diplomat tasked as the Chargé d'Affaires in the Indonesian Embassy in Tehran. My late parents lived in Tehran in the tail end of the Khomeini era, and happily enjoyed Persian hospitality for six memorable years.

Thus, my early exposure to Iran, Shia Islam and Middle Eastern politico-religious landscape began more than 25 years ago, having conversations with my own father, who was obviously quite well informed, after having met many Iranian and Middle Eastern leaders during his tenure in Tehran. Apart from enjoying the usual koobideh kebab and shopping at heavily subsidized prices, my time spent there provided me with an opportunity to meet regular Iranians, who harbored various ideological leanings and political sentiments. It seemed at the time that

Malaysia's Prime Minister. Just recently, Mahathir has toned down his anti-Shia sentiment by calling on Sunni Malaysians to accept Shias as Muslims. See: See: https://www.malaysia-today.net/2015/09/15/dr-m-tells-sunnis-to-accept-shias-asmuslims/ (accessed on December 18, 2018)

${ }^{10}$ Qum holds the Shrine of Fatimah Ma'sumah, the daughter of the revered Musa alKadzim, the seventh Imam, and sister of Ali ar-Ridha, the eighth Imam of the Shia Islam spiritual lineage. 
Iranians either loved Khomeini's revolution or hated it to the core, although the latter seemed much less than the former. It was difficult to envisage Iranians, or anyone for that matter, to be neutral about the Khomeini's revolution.

I also made an extra effort to practice my Farsi by talking to Iranians on the streets, shopkeepers, university students and taxi drivers in Tehran, both the formal and informal ones. During those days, the formal taxi drivers would drive around Pengeot 405 or the nationally-made orangecolored Paykan cars, while the non-formal ones could be driving anything from Mercedes or BMWs to Fiats. One just needed to say, "Mustaqeem, Agha?' (Straight ahead, Mister!), and the impromptu taxi driver would invite the passenger to join in the crowd of three or four other strangers in the car. As one can imagine, such short and spontaneous encounters usually stirred the most interesting conversations in Iran.

Tehran taxi drivers were particularly talkative, and have plenty to say about literally anything and everything under the sun. They certainly had strong opinions about the revolution and their leadership, and would often put you off track in your perception of Iranian politics. As I recall, the taxi drivers were very inquisitive about foreigners, curiously asking highly sensitive questions about religion, politics and how they felt about the regime, the Islamic revolution, even about freedom and democracy. Some would even go as far as asking me my religious school of thought (Aya shoma Sunni ya Shie hastiid?/Are you Sunni or Shia?), all just within a 10minute taxi ride.

However, anyone familiar with Iranian people and their culture, tarof or the practice of sugarcoating talk, could stand in the way of understanding the reality and much less the intention of why people say the things they say. ${ }^{11}$ Hence, tarof was one explanation why the nuclear negotiations took so many years to sign, only to be scrapped within a short period of time by President Donald Trump, which sent shockwaves to

11 Adam Cameron, "The Artful dodger: Iranian tarof and nuclear negotiations". In The Guardian (November 20, 2014). See: https://www.theguardian.com/world/iranblog/2014/nov/20/-sp-iran-nuclear-negotiations-tarof (accessed on April 2, 2018) 
Iran and US allies, namely the European counterparts. ${ }^{12}$ Since then, I have always watched developments in Iran and its impact on the Middle Eastern hemisphere. Such grounding has helped me tremendously to teach a course on Middle Eastern politics in the State Islamic University of Sunan Kalijaga in Yogyakarta, Indonesia.

As I was completing my Ph.D. program in 2003, my dissertation research took me back to Iran, where I conducted a survey research in Tehran, Qum, Qazvin and Esfahan. Predictably, the survey research was conducted not long after the 911 terrorist attacks on American soil, which hardened the stance on US foreign policymakers against anything resembling "Islamic fundamentalism". And as the war and subsequent invasion in neighboring Afghanistan and Iraq unfolded, domestic tension in Iran was at its pinnacle. To the Iranians and many Muslims around the world, including in Indonesia, president Bush's "war on terror" was becoming eerily perceived as a "war on Islam".

What is more, during the time I conducted the research in Iran, university students across the country were protesting against the government for the inexorable economic stagnation and what many had thought of as a process of political decay. In response to the volatile situation, the Rabbar (Supreme Leader) Ali Khamenei and government leaders bluntly accused the kharejis (foreigners) behind the wave of demonstrations across the country and university campuses. As a foreign researcher in Iran, it was obviously a tense and sensitive moment for the country. I was duly informed that foreign scholars and researchers were probably spied on, and that I had to watch my back.

\section{Mesmerizing Persian Intellectual Tradition}

Notwithstanding the incessant diplomatic spats with the US and the resulting isolation from the international community (read: mostly North American and Western European countries), Iran was able to attract

\footnotetext{
12 For a good chronology of events pertaining to the nuclear deal with Iran, see: https://www.armscontrol.org/factsheet/Timeline-of-Nuclear-Diplomacy-With-Iran (accessed on March 10, 2019).
} 
students and scholars from different corners of the world to study in the country with all expenses paid for by government scholarships or by the network of Husseiniyahs or Islamic Shia theological seminaries. Surprisingly, interest in studying in Iran came not only from Muslims, but also non-Muslims. The choice of subjects was also wide open. Some studied 'secular' subjects such as Persian Literature, Architecture, International Relations, Political Science and Engineering, while the religiously-oriented scholars and students understandably opted to do their stint in the numerous theological seminaries in Qum.

Since the revolution, Indonesians have been mesmerized by Iranian Shia scholars and ideologues of the Islamic revolution, namely Murtadha Mutahhari, Ali Syariati, Thabathaba'i, Khomeini and a whole host of other giant historical figures in literature such as Sa'adi, Hafez and Rumi. Not long, Indonesia was inundated by translated books on Shia Islam, the revolution, irfan (gnosticism), Velayat-e Fagheh (Guardianship of the Jurist)_Iran's political ideology and system in absence of the 'hidden' Imam named Mahdi al-Muntazhar (the Awaited One). Seizing the opportunity, while wanting to earn extra cash to pay for my college education, I jumped on the bandwagon, and translated two books of Mutahhari into Bahasa Indonesia for Mizan, which was and probably still is Indonesia's most bona fide Islamic publisher. ${ }^{13}$

One of the foremost reasons for Indonesian Muslims' enchantment toward Iran is its deep and long intellectual tradition, which Shia scholars have successfully maintained and developed over the centuries. Many of the books published and translated from Iran have brought many fresh ideas and perspectives in the fields of theology, philosophy, theosophy, irfan (mysticism), literature, politics and ethics.

In 2012, I was invited to speak in an international conference entitled Akblaak-e va Adyan (Ethics and Religions) in Qum, along with ethicists from around 10 countries, including the US. The conference,

\footnotetext{
${ }^{13}$ Since its establishment in the 1980s, Mizan has always been perceived to be a Shia publishing house, although it also produces numerous other non-specific Shia books on Sufism, Islamic philosophy, education, etc.
} 
hosted by Bonyad-e Esra (Esra Foundation), headed by the influential Ayatullah Javadi Amuli, a former Imam of the Friday prayer in Qum. The spirit of the conference seemed to emphasize the need to rationalize and universalize ethics, while still attempting to link it with Islamic revealed knowledge.

Indeed, the most worrying development, as far as the West is concerned, relates to Iran's scientific advancement on uranium enrichment, nuclear technology and its aggressive intercontinental ballistic missiles. Once Iran is able to truly combine these three capacities, there is every reason for the US, its European allies, Israel and its Arab neighboring countries to worry about it. But until today, there is hardly any clear proof that Iran is developing weapons of mass destruction, which the Americans and Israelis have persistently accused Iran of doing for almost two decades now.

It was within this context that Iranian president Mahmoud Ahmadinejad received the hero's welcome when he visited Indonesia's capital city of Jakarta, and among others spoke to thousands of faculty members and students of the State Islamic University of Syarif Hidayatulah in May 2006. The controversial yet popular Ahmedinejad was highly instrumental during the early stages of the nuclear standoff between Iran and the US. Ahmadinejad had persistently argued that enriching uranium was his nation's "right". During his tenure, Ahmadinejad had said on numerous occasions, including in Indonesia, that while the US had dropped atomic bombs in Hiroshima and Nagasaki, and effectively massacred hundreds of thousands of innocent lives, Iran had never engaged in such barbaric acts.

Meanwhile, Iran contends that access to nuclear technology is crucial in order for the country to build nuclear power plants that could produce electricity for the whole country and more. The Supreme Leader Ali Khamenei had also issued a fatwa (legal opinion or ruling) dating back to the mid-1990s that it was forbidden for Iran to produce weapons of 
mass destruction. ${ }^{14}$ This is in spite of the fact that the country became a victim of chemical and biological weapons during its eight bloody years of war with Saddam Hussein, whom the US, its Western allies and virtually all Arab neighbors vehemently supported.

During the $32^{\text {nd }}$ International Conference for the Proximity and Unity of the Muslim Nation, held in Tehran in late November 2018, to which I attended, the Supreme Leader Khamenei again voiced Iran's resistance against US domination and Western pressure, and advised Muslim countries to "return to the rule of Islam and come under the authority of Allah because the rule of America and Satan will not benefit you." ${ }^{\prime 15}$ The Rahbar, together with the incumbent President Hassan Rouhani, also underlined the treachery of Arab and Muslim nations, which sought aggression and destruction in Palestine, Syria and Yemen, while forging to normalize relations with Israel.

\section{Conclusion}

It has been argued for sometime that with the political ascendancy of Iranian-linked governments and groups across the Middle East, a "Shia revival" is unfolding in the region. ${ }^{16}$ While this may be true of the Middle East, the argument seems far-fetched in Southeast Asia. Even for Indonesia as the largest Muslim country in the region and the world, only between 150 and 200 students are studying in Iran at any given time. This is a far cry from the thousands of Indonesian scholars and students who venture to Al-Azhar University in Cairo, Egypt, and way much less than those who choose to study in the US, Europe and other Western countries.

\footnotetext{
${ }^{14}$ For more reading, see Michael Eisenstadt and Mehdi Khalaji, "Nuclear Fatwa Religion and Politics in Iran's Proliferation Strategy", Washington Institute for Near East Policy, No.115, September 2011.

${ }^{15}$ https://www.presstv.com/Detail/2018/11/25/581063/Iran-Leader-AyatollahKhamenei

${ }_{16}$ Vali Nasr, The Shia Revival: How conflicts within Islam will shape the future, W.W. Norton and Company, 2006.
} 
Despite the rising number of Shia institutions, organizations and groups linked to Iran in Indonesia, there is simply not enough critical mass in Indonesia and in Southeast Asia to forge ahead with the kind of revolutionary zeal that was once a source of concern for many Muslimpopulated countries. The irrational fear and hate mongering against Shia Islam-being propagated profusely by mostly Salafi-Wahhabi-Jihadi proponents in social media, especially during the height of the Syrian war-stems mostly from sheer ignorance among Muslim scholars and leaders on the diversity within Islam and the inability to grasp the complicated and fragmented Middle Eastern geopolitics.

There is no doubt that the spirit of the Islamic Revolution of Iran remains strong after forty tumultuous years despite international sanction, intimidation and isolation. The fact that the mullah government still remains in power seems to have proven its survivability amid a hostile world and unfriendly neighbors that choose not to give Iran the benefit of doubt. For many people in the country and region, Iran's longevity symbolizes the determination and steadfastness of David, who is fighting against Goliath.

While Iran has limited political and economic clout over Indonesia or Southeast Asia in general, its main soft power-Shia Islam—still holds sway among Muslim intellectuals and those who desire to see less domination, intimidation and condescension by the US and its Western allies.

\section{Bibliography}

Cameron, Adam. "The Artful dodger: Iranian tarof and nuclear negotiations," The Guardian (November 20, 2014). See: https://www.theguardian.com/world/iran-blog/2014/nov/20/sp-iran-nuclear-negotiations-tarof (accessed on April 2, 2018)

Eisenstadt, Michael and Khalaji, Mehdi. "Nuclear Fatwa Religion and Politics in Iran's Proliferation Strategy," W ashington Institute for Near East Policy, No.115, September 2011. 
https://warontherocks.com/2019/05/an-open-letter-to-presidentdonald-trump-on-u-s-tensions-with-iran/ (accessed on May 25, 2019).

https://www.armscontrol.org/factsheet/Timeline-of-Nuclear-

Diplomacy-With-Iran (accessed on March 10, 2019).

https://www.malaysia-today.net/2015/09/15/dr-m-tells-sunnis-toaccept-shias-as-muslims/ (accessed on December 18, 2018)

https://www.ncr-iran.org/en/freeiran2017/23114-john-bolton-iranregime-must-not-reach-40th-birthday (accessed on August 7, 2018).

https://www.presstv.com/Detail/2018/11/25/581063/Iran-LeaderAyatollah-Khamenei

Nasr, Vali. The Shia Revival: How Conflicts within Islam will Shape the Future. W.W. Norton and Company, 2006.

Sofjan, Dicky. "Minoritization and Criminalization of Shia Islam in Indonesia," Journal of South Asian and Middle Eastern Studies, Villanova University, Vol.39 (2), 2016.

Yoshihara, Kunio. The Rise of Ersatz Capitalism in Southeast Asia. Singapore: Oxford University Press, 1988. 